\title{
6.1 Міжнародно-правові стандарти професійної діяльності адвоката в цивільному процесі України
}

Обраний державою курс на європейську інтеграцію зумовлює необхідність впровадження в національні норми права законодавчих ініціатив, які стосуються специфіки професійної діяльності адвокатів, зокрема в цивільному процесі. Наразі у зв'язку з проведенням судової реформи інститут правової допомоги зазнає суттєвих змін. 3 огляду на це набуває актуальності дослідження міжнародного законодавства, яке регулює питання професійної діяльності адвокатів у цивільному процесі.

Впродовж останніх років в Україні проводиться активна діяльність 3 удосконалення правової допомоги, яка надається адвокатами у формі цивільного процесуального представництва.

Суб’єктами законодавчої ініціативи запропоновано внесення деяких змін до нормативно-правових актів, що стосуються професійної діяльності адвокатів [169-171]. Так, Указом Президента України від 20.05.2015 р. схвалено «Стратегію реформування судоустрою, судочинства та суміжних правових інститутів на 2015-2020 роки». У ній закріплюються основні положення щодо реформування надання правової допомоги в Україні та професійної діяльності адвокатів, а також приведення законодавства України у відповідність до європейських стандартів [172]. У зв'язку з цим можна погодитися 3 думкою В. О. Святоцької, яка, досліджуючи актуальні питання адвокатури України у світлі євроінтеграційних прагнень, наголошує, що з часів здобуття нашою країною незалежності адвокатура як важливий інститут правової системи держави перебуває у стані постійного реформування. Вона зазначає, що на долю української адвокатури випало чимало випробувань, адже законодавство стосовно неї постійно видозмінювалося, а їі становлення та розвиток завжди залежали від особливостей становлення самої держави та специфіки ії механізмів управління [173, с. 109]. 
У межах роботи заслуговує на увагу п. 5 ч. 1 Додатку до Резолюції (78) 8 Комітету міністрів Ради Європи «Про юридичну допомогу та консультації» від 02.03.1978 p., в якому закріплено, що юридична допомога завжди повинна здійснюватися особою, яка має право практикувати в якості адвоката відповідно до юридичних норм конкретної держави. У ньому також зазначається, що участь адвоката може бути як у разі, коли система юридичної допомоги передбачає це, так і у випадках, коли: а) сторони повинні бути представлені адвокатом у судовому органі конкретної держави відповідно до закону; б) є визначення з боку органу, який правомочний розглядати питання про надання юридичної допомоги того, що послуги адвоката є необхідними з огляду на конкретні обставини справи [175].

Ураховуючи вищенаведені положення, слід зазначити, що адаптація законодавства України стосовно виключного процесуального представництва адвокатом у суді є правильним кроком. У той же час в юридичній літературі положення, які викладені у Резолюції, не знайшли повної й беззаперечної підтримки. Так, С.С. Бичкова та А.В. Чурпіта, критично досліджуючи законодавчі зміни щодо інституту представництва в цивільному процесі, наголошують, що доцільним $є$ допуск в якості процесуальних представників не тільки адвокатів. Зазначені автори вважають, що варто допускати в якості процесуальних представників й інших осіб, які відповідають встановленим Законом вимогам [176, с. 27].

Важливі європейські стандарти професійної діяльності адвокатів закріплено у Кодексі поведінки європейських адвокатів. Зокрема, у ньому визначаються норми надання адвокатом різних видів правової допомоги 3 дотриманням принципів здійснення адвокатської діяльності (незалежності, довіри й особистої порядності, конфіденційності), розмірів та виплат гонорарів, правил поведінки адвокатів у суді та між собою. Особливе значення мають положення 5.8 Кодексу, що адвокати повинні підтримувати й розвивати свої професійні знання та навички з належним урахуванням авторитету своєї професії [177]. 
Не менш важливе значення для професійної діяльності адвокатів мають Загальні принципи для спільноти юристів, прийняті Міжнародною асоціацією юристів 20.09.2006 р. в м. Чикаго. У цьому документі відзначається, що юристи в усьому світі є професіоналами, які спеціалізуються з права, ставлять інтереси своїх клієнтів вище своїх власних і намагаються домогтися поваги до верховенства права [178].

Крім того, відповідно до Основних положень про роль адвокатів від 01.08.1990 р. останні, як важливі учасники здійснення правосуддя, мають постійно дбати про честь і гідність своєї юридичної професії [179]. Принципи діяльності адвокатів закріплено також і в іншому міжнародному документі від 07.09.1990 р., що стосується ролі юристів [180]. Наступним нормативним актом, який займає важливе місце в правовому регулюванні професійної діяльності адвокатів на теренах Свропейського Союзу, є Загальний кодекс правил від 01.10.1988 p. [181], у п. 1.1 якого закріплено, що у будь-якому правовому суспільстві адвокату відведено особливу роль, а його призначення не обмежено сумлінним виконанням свого обов'язку у межах закону. Адвокат має діяти в інтересах права в цілому так само, як і в інтересах тих, чиї права і свободи йому довірено захищати. Адвокат повинен не лише виступати в суді від імені клієнта, а й надавати йому юридичну допомогу у вигляді порад і консультацій. Поряд із цим даний документ ретельно врегулював питання щодо принципів адвокатської діяльності, зокрема щодо незалежності, довірчих відносин між клієнтом і адвокатом, конфіденційності діяльності та ін. Він містить також низку положень щодо особистої реклами адвоката та його взаємовідносини з клієнтами, судом, іншими адвокатами та ін. [181].

3 огляду на проведення в Україні правових реформ, а також специфіку надання адвокатами правової допомоги при захисті цивільних прав й охоронюваних законом інтересів, видається доцільним використання позитивного зарубіжного досвіду, закріпленого у вищенаведених міжнародних нормативно-правових документах. Разом із цим визначення єдиного напрямку реформування адвокатури в цивільному процесі зумовлено наявністю 
суперечливих пропозицій (законодавчих ініціатив) щодо концентрації повноважень представництва виключно адвокатами. У цьому аспекті варто зазначити, що Законом України «Про внесення змін до Конституції України (щодо правосуддя)» від 02.06.2016 р. Основний Закон України було доповнено новою статтею 131-2, де вказано, що виключно адвокат здійснює представництво іншої особи в суді, а також захист від кримінального обвинувачення [182].

Поряд із цим прийнятий 02.06.2016 р. Закон України «Про судоустрій i статус суддів» у змісті ст. 10 ч. 3 закріплює, що для надання професійної правничої допомоги діє адвокатура. Забезпечення права на захист від кримінального обвинувачення та представництво в суді здійснюється адвокатом, за винятком випадків, установлених законом [183].

На нашу думку, логічним кроком з наближення цивільного процесуального законодавства України, що регулює правовідносини надання кваліфікованої правової допомоги зацікавленим особам, зокрема щодо професійного представництва адвоката в цивільному процесі, до міжнародних стандартів професійної діяльності адвокатів, $є$ оновлення змісту Цивільного процесуального кодексу України (далі - ЦПК України) відповідно до наведених вище конституційних положень. 3 огляду на це науковцями пропонується доповнити ЦПК України новою статтею 401 «Адвокат як професійний представник у справі» в такій редакції: «Адвокат як професійний представник у цивільній справі - це особа, яка має повну вищу юридичну освіту, свідоцтво на право зайняття адвокатською діяльністю та здійснює діяльність 3 надання правової допомоги у цивільній справі на професійній основі, належним чином використовуючи власні повноваження. Адвокат, який бере участь у справі на стороні клієнта, може ініціювати укладення мирової угоди між сторонами. Адвокат може висловити намір про відмову від позову у разі, якщо він $\epsilon$ представником позивача, та про визнання позову у разі, якщо він $\epsilon$ представником відповідача. Повноваження адвоката, який представляє свого клієнта в суді, повинні бути посвідчені договором про надання правової 
допомоги або ордером чи довіреністю. Адвокат за вимогою суду повинен пред’явити своє посвідчення [169].

Адвокат як представник у цивільній справі повинен завжди сумлінно прагнути до досягнення максимально ефективного результату, якого потребує клієнт, дотримуючись правил, які встановлені цим Кодексом, Законом України «Про судоустрій і статус суддів», Законом України «Про адвокатуру та адвокатську діяльність» та іншим законодавством України». В обгрунтування пропонованої норми слід зазначити, що внесення вказаної статті до ЦПК України буде логічним результатом удосконалення процесуального законодавства, що належним чином співвідноситься 3 реформуванням професійної адвокатської діяльності, а також 3 міжнародними стандартами професійної діяльності адвокатів.

На основі аналізу міжнародних нормативних актів, що закріплюють положення стосовно професійної діяльності адвокатів, зокрема в цивільному процесі, до європейських стандартів професійної діяльності адвокатів запропоновано віднести такі: 1) надання правової допомоги виключно адвокатами; 2) достатню кваліфікацію та досвід адвокатів як професійних юристів; 3) конфіденційність і незалежність адвокатської діяльності; 4) адвокат, здійснюючи свою професійну діяльність з надання правової допомоги клієнту, повинен завжди діяти в інтересах останнього (у межах законодавства); 5) право адвоката на винагороду (гонорар) за здійснення професійної діяльності; 6) професійне страхування адвокатської діяльності з метою правового захисту адвоката; 7) підкорення адвоката, як професійного юриста, відповідним правилам (нормам законодавства), що регулюють питання етичної поведінки під час надання правової допомоги в судах; 8) порядність і чесність професійної адвокатської діяльності; 9) наявність духу корпоративності та взаємної підтримки між адвокатами; 10) повага до інтересів усіх учасників судового процесу; 11) застосування заходів процесуального примусу до адвокатів у разі вчинення ними правопорушень. 